\begin{tabular}{ll}
\hline Homepage: http://jusami.batan.go.id & Jurnal Sains Materi Indonesia \\
\hline & $\begin{array}{l}\text { Akreditasi LIPI } \\
\text { No.: 602/AU3/P2MI-LIPI/03/2015 } \\
\text { Tangal 15 April 2015 } \\
\text { ISSN : 1411-1098 }\end{array}$ \\
\hline
\end{tabular}

\title{
TEKNOLOGI EKSTRAKSI FLUIDA SUPERKRITIS DAN MASERASI PADA ZINGIBER OFFICINALLE ROSCOE : AKTIVITAS ANTIOKSIDAN DAN KANDUNGAN FITOKIMIA
}

\author{
Dewi Sondari dan Eka Dian Puspitasari \\ Pusat Penelitian Kimia (P2K) - LIPI \\ Kawasan Puspiptek, Serpong 15314, Tangerang Selatan \\ E-mail : sondaridewi@yahoo.com
}

Diterima: 13 Oktober 2016

Diperbaiki: 28 Desember 2016

Disetujui: 9 Januari 2017

\begin{abstract}
ABSTRAK
TEKNOLOGI EKSTRAKSI FLUIDA SUPERKRITIS DAN MASERASI PADA ZINGIBER OFFICINALLE ROSCOE : AKTIVITAS ANTIOKSIDAN DAN KANDUNGAN FITOKIMIA. Proses ekstraksi Zingiber officinale Roscoe dengan metode fluida superkritis dan metode maserasi sebagai pembanding telah dilakukan. Ekstraksi $\mathrm{CO}_{2}$ superkritis dilakukan pada kondisi proses tekanan $12-16 \mathrm{MPa}$, suhu $20-40{ }^{\circ} \mathrm{C}$, waktu ekstraksi 2-6 jam dan laju alir fluida $\mathrm{CO}_{2}$ superkritis 5,5 mL/menit. Pengaruh proses ekstraksi terhadap rendemen, aktivitas antioksidan dan kandungan fitokimia dari Zingiber officinale Rosc telah diteliti. Hasil penelitian ekstrak kasar jahe menunjukkan bahwa rendemen tertinggi $2,99 \mathrm{mg} / \mathrm{g}$ diperoleh pada suhu $40{ }^{\circ} \mathrm{C}$, tekanan $16 \mathrm{MPa}$ dan waktu ekstraksi 6 jam, dengan kandungan fenol total 72,73 mg GEA/g ekstrak, flavonoid total $0,90 \%$ (b/b) dan aktivitas antioksidan sebesar $63,66 \mu \mathrm{g} / \mathrm{mL}$. Hasil ekstrak kasar jahe dengan metode maserasi dihasilkan rendemen 3,10 mg/g, dengan kandungan phenol total 76,68 mg GEA/g ekstrak, flavonoid total $1,18 \%(\mathrm{~b} / \mathrm{b})$ dan aktivitas antioksidan sebesar $122,85 \mu \mathrm{g} / \mathrm{mL}$.
\end{abstract}

Kata kunci: Ekstraksi $\mathrm{CO}_{2}$ superktritis, Flavonoid, Phenol, Rendemen, Zingiber officinale Rosc

\begin{abstract}
SUPERCRITICAL FLUID EXTRACTION TECHNOLOGY AND MACERATION OF ZINGIBER OFFICINALLE ROSCOE : ANTIOXIDANT ACTIVITY AND PHYTOCHEMICAL CONTENT. The process of extracting Zingiber officinale Roscoe with supercritical fluids and maceration method as a comparison has been done. $\mathrm{CO}_{2}$ supercritical fluid at extractions were performed operating pressure in the range of 12-16 MPa, with temperature $20-40{ }^{\circ} \mathrm{C}$, extraction time 2-6 hours and flow rate $5.5 \mathrm{~mL} / \mathrm{min}$. Effect of extraction to the yield, antioxidant activity and phytochemical content of Zingiber officinale Rosc was observed. Results showed that the crude extract from Zingiber officinale Rosc exhibits higher extraction yield with $2.99 \mathrm{mg} / \mathrm{g}$ was obtained at $40{ }^{\circ} \mathrm{C}$, the pressure of $16 \mathrm{MPa}$ and extraction time of 6 hours, with a phenol total content of $72.73 \mathrm{mg}$ GEA/g extracts, flavonoid totals $0.90 \%(\mathrm{w} / \mathrm{w})$ and activity antioxidants at $63.66 \mu \mathrm{g} / \mathrm{mL}$. Results showed of ginger crude extract with maceration method resulting yield of $3.10 \mathrm{mg} / \mathrm{g}$, with a phenol total content of $76.68 \mathrm{mg} \mathrm{GEA} / \mathrm{g}$ extracts, flavonoid totals $1.18 \%(\mathrm{w} / \mathrm{w})$ and antioxidant activity of $122.85 \mu \mathrm{g} / \mathrm{mL}$.
\end{abstract}

Keywords: Supercritical $\mathrm{CO}_{2}$ extraction, Flavonoid, Phenol, Yield, Zingiber officinale Rosc

\section{PENDAHULUAN}

Radikal bebas dalam tubuh manusia berasal dari metabolisme oksigen di tubuh dan dari lingkungan. Radikal bebas yang masuk ke dalam tubuh dapat bereaksi dengan biomolekul seperti asam deoksiribonukleat, protein dan lipid sehingga merusak fungsi biologisnya, dan menimbulkan penyakit seperti penyakit jantung koroner, stroke, kanker diabetas melitus dan katarak [1].

Zat antioksidan yang ada dalam tubuh tidak dapat sepenuhnya melawan dan menghancurkan radikal bebas yang ada di dalam tubuh terutama pada keadaan stress oksidatif, sehingga dibutuhkan antioksidan yang berasal 
dari luar tubuh yang didapatkan dari makanan seperti buah-buahan dan sayuran. Senyawa-senyawa yang sudah terbukti mempunyai aktifitas sebagai antioksidan adalah vitamin $\mathrm{C}$, vitamin $\mathrm{E}$, betakaroten, flavonoid, alkaloid, tanin, glikodida, kurkuminoid, serta senyawa fenol [1,2].

Banyak tanaman obat yang tumbuh di Indonesia yang mempunyai aktifitas antioksidan, salah satunya adalah rimpang jahe (Zingiber officinale Roscoe). Rimpang jahe emprit merupakan salah satu tanaman yang memiliki aktivitas antioksidan yang tinggi karena adanya kandungan flavonoid dan senyawa polifenol (6-gingerol dan turunannya) yang diketahui mampu menghambat pembentukan radikal bebas [2]. Antioksidan alami banyak digunakan karena memiliki efek samping yang lebih sedikit serta lebih aman, sedangkan antioksidan sintetik telah dibatasi penggunaannya karena diduga memiliki efek toksik dan mungkin juga karsinogenik [1].

Studi mengenai aktivitas antioksidan dan antimokrobial oleoresin dari ekstrak jahe dan esensial oil telah dilakukan, proses ekstraksinya dilakukan dengan metoda sokletasi. Aktivitas antioksidan yang diperoleh pada oleoresin $\left(\mathrm{IC}_{50}=1820 \mathrm{mg} / \mathrm{mL}\right)$ lebih rendah bila dibanding dengan esensial oil $\left(\mathrm{IC}_{50}=110 \mathrm{mg} / \mathrm{mL}\right)$ [3]. Aktivitas antibakteri dari ekstrak jahe menggunakan $\mathrm{CO}_{2}$ superkritis sebagai pelarut dan minyak esensial jahe yang diperoleh dari teknik destilasi air dilakukan oleh Mesomo dkk [4]. Ekstraksi superkritis menggunakan $\mathrm{CO}_{2}$ dilakukan pada tekanan 10,0 MPa; 17,5 MPa dan 25,0 MPa dan pada suhu $293,15 \mathrm{~K} ; 313,15 \mathrm{~K}$ dan 333,15 K. Hasil ekstrak rimpang jahe menggunakan ekstraksi superkritis sebesar $2,62 \%$ berat dan $1,79 \%$ berat untuk ekstraksi destilasi air. Komposisi kimia hasil ekstraksi dari kedua metode diatas menggunakan metoda gas kromatografi. Hasil kromatogram menunjukkan jumlah dan senyawa yang terkadung dalam rimpang jahe berbeda-beda, tergantung pada proses ekstraksi yang digunakan. Komponen utama hasil ekstrak jahe menggunakan ekstraksi superkritis adalah $\alpha$-zingiberene, $\beta$-sesquiphellandrene, $\alpha$-farnesene, geranial, $\beta$-bisabolene dan $\beta$-eudesmol. Komponen utama minyak esensial hasil ekstrak dengan menggunakan destilasi air adalah $\alpha$ - curcumene, geranial dan camphene adalah komposisi yang paling banyak.

Kualitas ekstrak sangat dipengaruhi oleh metodologi ekstraksi yang digunakan dan jenis pelarutnya. Untuk ekstraksi bahan bioaktif dari tanaman dapat menggunakan metode ekstraksi dengan pelarut air, etanol, campuran air dan etanol dan ekstraksi fluida superkritis [4].

Ekstraksi berbasis pelarut organik (non polar) memberikan hasil (rendemen) ekstrak yang rendah, waktu ekstraksi yang relatif lama, pelarut yang digunakan sangat banyak, hasil ekstrak mengandung residu sisa pelarut organik beracun, tidak selektif, dan untuk memperoleh senyawa aktif/bahan aktif yang murni diperlukan beberapa treatment/pemurnian seperti penghilangan bahan-bahan klorofil, penghilangan bahan pengotor dan lain sebagainya sehingga memerlukan biaya yang relatif tinggi. Residu pelarut organik beracun akan menimbulkan masalah karena menyebabkan kualitas hasil ekstrak memburuk dan dapat menyebabkan masalah kesehatan yang serius ketika hasil ekstrak diambil ke dalam tubuh manusia. Oleh karena itu diperlukan pemanasan dan tekanan vakum yang tinggi untuk menguapkan sisa residu pelarut organik dalam hasil ekstrak, sehingga energi yang diperlukan menjadi lebih besar dan hal ini berhubungan dengan harga biaya yang harus dikeluarkan [5-7].

Ekstraksi fluida superkritis (SFE), terutama karbon dioksida superkritis $\left(\mathrm{SCCO}_{2}\right)$ adalah alternatif ekstraksi yang potensial untuk mengambil bahan bioaktif dari tanaman herbal bila dibandingkan dengan ekstraksi cair menggunakan pelarut (ekstraksi konvensional)[8]. Ekstraksi fluida superkritis (SFE) merupakan teknologi yang menarik buat industri makanan, kosmetik dan industri farmasi, sebagai alternatif untuk proses konvensional seperti ekstraksi pelarut dan destilasi uap, untuk mendapatkan minyak esensial dan oleoresin yang bebas dari residu, di samping itu, dapat dilakukan pada suhu rendah, yang diperlukan untuk meningkatkan kualitas produk thermosensitive.

Ekstraksi fluida superkritis mempunyai kelebihan yaitu lebih efisien karena waktu ekstraksi lebih pendek, tidak beracun, dan alternatif ramah lingkungan, kemurnian dan kelarutan yang lebih tinggi, dan biaya ekstraksi pelarut lebih rendah karena sistem dalam ekstraksi fluida superkritis, pelarutnya dapat di daur ulang (recycle) dan mengurangi masalah yang terkait dengan degradasi termal senyawa secara signifikan. Sedangkan kerugian utama dari ekstraksi $\mathrm{CO}_{2}$ fluida superkritis adalah bahwa ekstraksi komponen polar sangat dibatasi oleh kekuatan pelarut $\mathrm{CO}_{2}[9-11]$.

Pelarut ini, selain memiliki titik kritis dalam kondisi yang relatif ringan dan biaya menjadi rendah, tersedia dalam jumlah yang banyak, tidak beracun, mudah terbakar, mudah dihapus dari bahan yang diekstraksi dan ramah lingkungan. Dalam kondisi tertentu, ketika $\mathrm{CO}_{2}$ superkritis digunakan sebagai pelarut dalam ekstraksi senyawa termolabil, terutama senyawa antioksidan, aktivitas antioksidan dari senyawa ini relatif tinggi jika dibandingkan dengan pelarut organik. Hal ini karena dalam proses konvensional yang menggunakan pelarut organik, oksidasi senyawa terjadi selama pemurnian pelarut [12].

Tujuan dari penelitian ini adalah untuk melihat aktifitas antioksidan dan kandungan fitokimia dari Zingiber officinale dengan menggunakan ekstraksi fluida superkritis pada tekanan $12 \mathrm{MPa}$ hingga $16 \mathrm{MPa}$, suhu $20{ }^{\circ} \mathrm{C}$ hingga $40{ }^{\circ} \mathrm{C}$ dan waktu ekstraksi 2 jam hingga 6 jam. Penelitian ini berbeda dengan yang telah 
dilakukan oleh peneliti sebelumnya [4, 12], yang dalam penelitian menggunakan co-solvent. Sebagai pembanding, proses ekstraksi dengan metode maserasi juga dilakukan menggunakan pelarut campuran etanol:air (70\% v/v) selama 24 jam [13].

\section{METODE PERCOBAAN}

\section{Bahan Baku dan Alat}

Simplisia Zingiber officinale Roscoe, gas $\mathrm{CO}_{2}$ teknis dari CV. Krakatau Raya, etanol teknis dari Brataco, aquadest dari Pusat Penelitian Kimia LIPI, metanol, reagent $\mathrm{DPPH}$, asam galat, reagent Folin-Ciocalteu, natrium karbonat, etanol, quercetin, alat ekstraksi fluida superkritis model 46-19360 buatan Newport Scientific, Inc, reaktor dari stainless, alat spektrofotometer, alatalat gelas, timbangan, dan hot plate.

\section{Cara Kerja}

\section{Ekstraksi Maserasi}

$1 \mathrm{~kg}$ dari Zingiber officinale Rosc direndam dalam etanol: air (70\% v/v) selama 1 x 24 jam ekstrak yang diperoleh dievaporasi untuk mendapatkan ekstrak kering [13].

\section{Ekstraksi Fluida Superkritis Zingiber officinale Roscoe}

Ekstraksi fluida superkritis untuk jahe dilakukan dengan variasi terhadap suhu, waktu ekstraksi dan tekanan. Kondisi operasi : suhu $20{ }^{\circ} \mathrm{C}, 30{ }^{\circ} \mathrm{C}, 40{ }^{\circ} \mathrm{C}$, tekanan $12 \mathrm{MPa}, 14 \mathrm{MPa}$ dan $16 \mathrm{MPa}$, waktu 2 jam, 4 jam dan 6 jam, sedangkan laju alir fluida superkritis dibuat konstan 5,5 mL/min [14]. 60 gram Zingiber officinale Rosc dengan kadar air 12,01\% dimasukkan ke dalam keranjang extractor dan ditempatkan dalam wadah ekstraksi (Model 46-19360 Newport Scientific, Inc). Gas $\mathrm{CO}_{2}$ didinginkan dalam chiller hingga suhu $4{ }^{\circ} \mathrm{C}$, kemudian atur suhu dan tekanan proses ekstraksi. Hasil ekstrak kasar di sampling pada akhir proses ekstraksi.

\section{Rendemen Ekstraksi}

Rendemen ekstrak kasar dapat dihitung dengan menggunakan Persamaan (1) berikut :

$$
\text { Rendemen }(\mathrm{mg} / \mathrm{g})=\frac{\text { Berat ekstrak kasar }(\mathrm{mg})}{\text { Berat sampel kering }(\mathrm{g})}
$$

\section{Uji Antioksidan}

Aktivitas antioksidan dari ekstrak terhadap radikal bebas 2,2-diphenyl-1,1-picryl hydrazyl (DPPH) dilakukan dengan metode yang telah dilakukan peneliti sebelumnya[15]. Larutan ekstrak (10-200 $\mu \mathrm{g})$ dalam $2 \mathrm{~mL}$ metanol ditambahkan larutan 0,5 mL DPPH (1 mM dalam metanol). Campuran dikocok dan didiamkan pada suhu ruang selama 35 menit. Serapan yang dihasilkan diukur pada panjang gelombang $517 \mathrm{~nm}$. Persen inhibisi sampel dihitung berdasarkan perbedaan serapan antara blanko dan sampel seperti Persamaan (2).

Peredaman DPPH-scavenging $(\%)=\left[1-\left(\mathrm{A}_{\mathrm{s}} / \mathrm{A}_{0}\right) \times 100\right]$..(

Dimana:

$$
\begin{aligned}
& A_{0}=\text { Absorban blanko } \\
& A_{s}=\text { Absorban sampel }
\end{aligned}
$$

Persentase aktivitas peredaman DPPH diplotkan terhadap konsentrasi sampel. Nilai peredaman $50 \%\left(\mathrm{IC}_{50}\right)$ dihitung dari grafik persentase peredaman terhadap konsentrasi sampel. Pengujian dilakukan 2 kali pengulangan, dan Quercetin, digunakan sebagai pembanding.

\section{Analisis Kandungan Fenol Total}

Penentuan senyawa fenol total ditentukan dengan metoda Folin-Ciocalteu [16], menggunakan asam galat sebagai standar. Konsentrasi total senyawa fenol dalam ekstrak ditentukan sebagai asam galat setara (g GAE/mg ekstrak). Analisis dilakukan secara duplo. Membuat standar asam galat pada konsentrasi 0-35 ppm dan diukur absorbansi pada panjang gelombang $765 \mathrm{~nm}$. Satu mililiter ekstrak ditambahkan ke 0,5 mL metanol, 2,5 mL air deionisasi dan 2,5 mL Folin-Ciocalteu fenol reagent $50 \%$ (Merck-Schuchardt, Hohenbrunn, Jerman). Campuran kemudian didiamkan selama 15 menit dan 2,0 $\mathrm{mL}$ natrium karbonat ditambahkan ke dalam campuran, kemudian diinkubasi selama 15 menit pada suhu $45^{\circ} \mathrm{C}$. Absorbansi sampel diukur pada panjang gelombang $765 \mathrm{~nm}$ menggunakan $U V$-Vis spektrofotometer.

\section{Analisis Kandungan Flavonoid Total}

Kandungan senyawa flavonoid total dihitung berdasarkan metoda aluminium klorida [17]. Kandungan senyawa flavonoid total dinyatakan sebagai quercetin equivalen ( $\mathrm{mg} / \mathrm{g}$ ekstrak) berdasarkan persamaa regresi dari kurva kalibrasi. Larutan ekstrak $(500 \mu \mathrm{L})$ atau larutan standar quercetin $(50 \mu \mathrm{L}, 100 \mu \mathrm{L}$, $150 \mu \mathrm{L}, 200 \mu \mathrm{L}$ dan $250 \mu \mathrm{L})$ dipipet ke dalam tabung reaksi, kemudian ditambahkan $2 \mathrm{~mL}$ aquadest. Ke dalam tabung ditambahkan $150 \mu \mathrm{L} \mathrm{NaNO}_{2} 5 \%$. Setelah 5 menit, $150 \mu \mathrm{L} \mathrm{AlCl}_{3} 10 \%$ ditambahkan. Enam menit kemudian, $2 \mathrm{~mL} \mathrm{NaOH} 1 \mathrm{M}$ dan aquadest ditambahkan hingga volume menjadi $5 \mu \mathrm{L}$. Larutan dihomogenkan dan diukur serapannya pada panjang gelombang $510 \mathrm{~nm}$. Kadar flavonoid yang diperoleh adalah sebagai quercetin equivalen ( $\mathrm{mg} / \mathrm{g}$ ekstrak). 


\section{HASIL DAN PEMBAHASAN}

\section{Rendemen Ekstrak Jahe}

Ekstraksi fluida superkritis terhadap Zingiber officinale Rosc dilakukan pada suhu 20-40 ${ }^{\circ} \mathrm{C}$, tekanan 12-16 MPa dan waktu ekstraksi 2-6 jam. Pengaruh kondisi proses tekanan, suhu dan waktu terhadap rendemen ekstrak jahe dapat dilihat pada Tabel 1.

Tabel 1. Pengaruh waktu terhadap rendemen ekstrak Zingiber officinale Rosc

\begin{tabular}{cccc}
\hline $\begin{array}{c}\text { Suhu } \\
\left({ }^{\circ} \mathrm{C}\right)\end{array}$ & $\begin{array}{c}\text { Tekanan } \\
(\mathrm{MPa})\end{array}$ & $\begin{array}{c}\text { Waktu } \\
(\mathrm{Jam})\end{array}$ & $\begin{array}{c}\text { Rendemen } \\
(\mathrm{mg} / \mathrm{g})\end{array}$ \\
\hline 30 & 14 & 2 & 2,46 \\
30 & 14 & 4 & 2,64 \\
30 & 14 & 6 & 2,72 \\
\hline
\end{tabular}

Rendemen hasil ekstraksi fluida superkritis pada jahe dipengaruhi oleh kondisi proses tekanan, suhu maupun waktu ekstraksi sebagaimana ditunjukkan pada Tabel 1, Tabel 2 dan Tabel 3. Pada tekanan $14 \mathrm{MPa}$ dan suhu $30{ }^{\circ} \mathrm{C}$ dan waktu ekstraksi antara 2 sampai 6 jam, rendemen tertinggi $2,72 \mathrm{mg} / \mathrm{g}$ terhadap berat kering jahe, diperoleh pada waktu 6 jam. Semakin lama ekstraksi, rendemen yang diperoleh semakin tinggi, karena akan semakin lama pula pelarut dapat masuk dan memecah dinding sel tanaman, sehingga semakin banyak komponen-komponen senyawa yang terekstrak.

Tabel 2. Pengaruh tekanan terhadap rendemen ekstrak Zingiber officinale Rosc

\begin{tabular}{cccc}
\hline $\begin{array}{c}\text { Suhu } \\
\left({ }^{\circ} \mathrm{C}\right)\end{array}$ & $\begin{array}{c}\text { Tekanan } \\
(\mathrm{MPa})\end{array}$ & $\begin{array}{c}\text { Waktu } \\
(\mathrm{Jam})\end{array}$ & $\begin{array}{c}\text { Rendemen } \\
(\mathrm{mg} / \mathrm{g})\end{array}$ \\
\hline 30 & 16 & 6 & 2,86 \\
30 & 14 & 6 & 2,72 \\
30 & 12 & 6 & 2,50 \\
\hline
\end{tabular}

Tabel 3. Pengaruh suhu terhadap rendemen ekstrak Zingiber officinale Rosc

\begin{tabular}{cccc}
\hline $\begin{array}{c}\text { Suhu } \\
\left({ }^{\circ} \mathrm{C}\right)\end{array}$ & $\begin{array}{c}\text { Tekanan } \\
(\mathrm{MPa})\end{array}$ & $\begin{array}{c}\text { Waktu } \\
(\mathrm{Jam})\end{array}$ & $\begin{array}{c}\text { Rendemen } \\
(\mathrm{mg} / \mathrm{g})\end{array}$ \\
\hline 20 & 16 & 6 & 2,78 \\
30 & 16 & 6 & 2,86 \\
40 & 16 & 6 & 2.99 \\
\hline
\end{tabular}

Pada tekanan $16 \mathrm{MPa}$ dan suhu $40{ }^{\circ} \mathrm{C}$, dan waktu ekstraksi 6 jam, merupakan kondisi optimum dengan rendemen sebesar 2,99 mg/g terhadap berat kering jahe. Sedangkan rendemen jahe dengan menggunakan ekstraksi maserasi sebesar 3,10 $\mathrm{mg} / \mathrm{g}$ terhadap berat kering jahe. Rendemen jahe dengan menggunakan ekstraksi maserasi lebih besar bila dibandingkan dengan ekstraksi fluida superkritis, meskipun tidak signifikan (Tabel 1).

Rendemen terendah $2,46 \mathrm{mg} / \mathrm{g}$ terhadap berat kering jahe diperoleh pada suhu $30^{\circ} \mathrm{C}$, tekanan $14 \mathrm{MPa}$ dan waktu ekstraksi 2 jam. Hal ini menunjukkan bahwa waktu esktraksi mempengaruhi rendemen ekstrak, meskipun tekanan relatif tinggi dan densitas semakin tinggi, akan tetapi karena waktu untuk melarutkan komponen dan transfer massa relatif singkat sehingga hanya komponen-komponen tertentu yang dapat terekstrak dan mengakibatkan rendemen rendah.

Peneliti lain melaporkan hasil penelitian ekstraksi jahe menggunakan ekstraksi fluida superkritis pada kondisi optimum tekanan $25 \mathrm{MPa}$, suhu $60^{\circ} \mathrm{C}$ dan waktu ekstraksi 3 jam dengan rendemen sebesar 3,21\% (\%berat) [14]. Sedangkan peneliti lain melakukan penelitian ekstraksi jahe menggunakan fluida superkritis pada kondisi optimum tekanan 200 bar, suhu $35^{\circ} \mathrm{C}$ dan waktu ekstraksi 7 jam menghasilkan rendemen 2,65\% (\%berat) [12]. Perbedaan hasil rendemen ini menunjukkan bahwa selain kondisi proses ekstraksi, jenis pelarut dan teknologi proses yang digunakan, rendemen dan kandungan senyawa kimia yang terdapat dalam jahe dipengaruhi pula oleh lokasi tanaman dan kondisi lingkungan yang beragam [4,7].

Pada Tabel 2. dapat dilihat bahwa semakin tinggi tekanan pada proses ekstraksi fluida superkritis, maka akan semakin tinggi pula rendemennya. Rendemen pada tekanan $16 \mathrm{MPa}$, suhu $30^{\circ} \mathrm{C}$ dan waktu ekstraksi 6 jam sebesar 2,86 mg/g. Rendemen terkecil pada tekanan $12 \mathrm{MPa}$, suhu $30^{\circ} \mathrm{C}$ dan waktu ekstraksi 6 jam sebesar $2,50 \mathrm{mg} / \mathrm{g}$. Ekstraksi fluida superkritis sangat tergantung pada kondisi tekanan dan suhu superkritisnya. Pada kondisi kritis, gas $\mathrm{CO}_{2}$ menyerupai cairan yang mempunyai sifat dengan densitas tinggi, viskositas yang rendah dan difusifitas tinggi sehingga dapat mengekstrak komponen senyawa dalam suatu bahan secara selektif dan efektif.

Selain tekanan, kondisi suhu pada ekstraksi fluida superkritis mempengaruhi rendemen. Suhu yang digunakan dalam ekstraksi jahe divariasikan antara $20^{\circ} \mathrm{C}$ hingga $40^{\circ} \mathrm{C}$. Suhu yang digunakan relative lebih rendah karena jahe mempunyai sifat sebagai antioksidan, dimana senyawa yang mempunyai sifat sebagai antioksidan tidak tahan terhadap panas yang tinggi, karena akan mengakibatkan senyawa tersebut teroksidasi. Pada penelitian suhu $40{ }^{\circ} \mathrm{C}$, rendemen yang diperoleh sebesar $2,99 \mathrm{mg} / \mathrm{g}$ dan rendemen terendah pada suhu $20^{\circ} \mathrm{C}$ walaupun tidak signifikan (Tabel 3).

\section{Aktivitas Antioksidan Peredaman Radikal Bebas DPPH Zingiber officinale Roscoe}

Pengujian aktivitas antioksidan terhadap ekstrak jahe dilakukan untuk mengetahui potensi ekstrak jahe baik yang diekstraksi menggunakan fluida superkritis maupun dengan metode maserasi sebagai senyawa antioksidan.

Antioksidan merupakan suatu senyawa yang dapat melawan radikal bebas dan menghambat terjadinya oksidasi pada sel sehingga mengurangi terjadinya kerusakan sel dan membantu menekan proses penuaan 
dini. Radikal bebas secara normal akan diproduksi oleh tubuh sebagai akibat dari proses oksidasi, namun apabila radikal bebas dalam tubuh berlebihan akan menimbulkan suatu stress oksidatif yang diketahui akan menyebabkan kerusakan pada sel, dan menjadi suatu penyakit pada jaringan. Stress oksidatif adalah suatu keadaan dimana jumlah molekul radikal bebas dalam tubuh jumlahnya melebihi antioksidan dalam tubuh, yang akan menyerang komponen protein sehingga mengakibatkan kerusakan sel $[1,18]$.

Dari data hasil perhitungan, diketahui bahwa ekstrak jahe dengan menggunakan metoda superkritis pada tekanan $16 \mathrm{MPa}$ memberikan penghambatan paling besar yang ditandai dengan IC50 yang paling kecil di antara semua sampel, sebesar 63,66 $\mu \mathrm{g} / \mathrm{mL}$. Penghambatan aktivitas antioksidan terkecil pada tekanan $12 \mathrm{MPa}$ yaitu $129,35 \mu \mathrm{g} / \mathrm{mL}$ dan dengan menggunakan metode maserasi memberikan penghambatan sebesar $122,85 \mu \mathrm{g} / \mathrm{mL}$. Tingkat kekuatan antioksidan adalah kuat (IC50 <50 ppm), aktif (IC50 50-100 ppm), sedang (IC50 101-250 ppm), Lemah (IC50 250-500 ppm), dan tidak aktif (IC50>500 ppm) [19] seperti diperlihatkan pada Gambar 1.

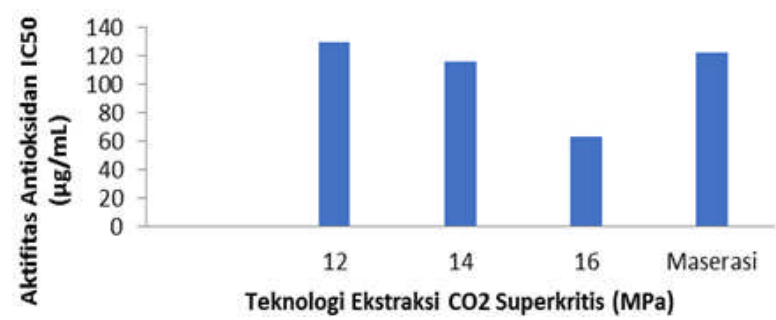

Gambar 1. Aktivitas antioksidan peredaman radikal bebas DPPH Zingiber officinale Rosc

Aktivitas antioksidan dari ekstrak tumbuhan berhubungan dengan senyawa bioaktif phytochemical yang menghasilkan aktivitas biologis yang positif bagi tubuh seperti misalnya, gingerol dan shogaols dalam jahe. Zancan menunjukkan hasil penelitiannya bahwa fraksi kaya gingerol dan shogaols menyajikan aktivitas antioksidan lebih tinggi dari fraksi lainnya [12].

Tidak adanya gingerol dan shogaol menyebabkan hilangnya $20 \%$ total aktivitas antioksidan. Komponen lainnya dalam jahe yang menyediakan aktivitas antioksidan, adalah sesquiphellandrene. Aktivitas antioksidan menengah, ditemukan dalam komponen ekstrak jahe yaitu $\alpha$-farnesene. $\alpha$-farnesene merupakan komponen yang terdapat dalam ekstrak jahe yang secara kimia tidak stabil dan dapat menjalani autoksidasi dengan mudah dengan adanya oksigen [12]. 6-Gingerol, yang merupakan komponen utama jahe, memiliki aktivitas antioksidan yang cukup besar [20].

Hasil analisis aktivitas antioksidan dan fenol total menunjukan hasil yang linier. Ekstrak jahe pada kondisi tekanan $16 \mathrm{MPa}$ memiliki aktifitas antioksidan tertinggi dan juga memiliki fenol total yang tinggi. Aktifitas antioksidan dan kandungan fenol terkecil diperoleh pada tekanan $12 \mathrm{Mpa}$.

\section{Kandungan Fenol Total dan Flavonoid Total Zingiber officinale Roscoe}

Analisis kandungan fenol total dilakukan untuk mengetahui potensi ekstrak jahe sebagai penangkal radikal bebas dan penstabil oksigen singlet. Komponen kimia yang berperan sebagai antioksidan adalah senyawa golongan fenol dan poliphenol. Senyawa-senyawa golongan tersebut banyak terdapat di alam, terutama pada tumbuh-tumbuhan, dan memiliki kemampuan untuk menangkap radikal bebas [1].

Penentuan kandungan fenol total dengan metode Folin-Ciocalteu dilakukan berdasarkan kemampuan reagen Folin-Ciocalteu mengoksidasi gugus hidroksil (OH-) dari senyawa golongan phenol. Analisis kandungan fenol total menggunakan metoda FolinCiocalteu yang absorbansinya diukur pada panjang gelombang $765 \mathrm{~nm}$ [16]. Kandungan fenol total pada masing-masing ekstrak dinyatakan sebagai ekuivalen asam galat atau Gallic Acid Equivalent (GAE)

Hasil penentuan kandungan fenol total dengan persamaan kurva standar asam galat yaitu $\mathrm{y}=0,66 \mathrm{x}+0,0108\left(\mathrm{R}^{2}=0,9845\right)$, menunjukkan bahwa senyawa golongan fenol banyak terdapat pada ekstrak jahe menggunakan ekstraksi maserasi sebesar 76,68 mg GEA/g ekstrak, artinya, dalam setiap gram ekstrak setara dengan 76,68 mg asam galat.

Tingginya kandungan fenol total karena senyawa golongan fenol bersifat polar dan sebagian semi polar, sehingga ekstraksi menggunakan metoda maserasi dengan pelarut campuran etanol-air ( $70 \%$ berat) akan lebih mudah mengekstrak senyawa golongan phenol. Flavonoid yang merupakan golongan terbesar dari senyawa fenol bersifat polar sehingga akan banyak terdapat pada ekstrak menggunakan pelarut campuran etanol-air. Sementara, pada ekstrak jahe menggunakan ekstraksi fluida superkritis dimungkinkan banyak terdapat aglikon flavonoid yang bersifat kurang polar, sehingga kandungan phenolnya lebih rendah.

Tingginya kandungan fenol yang terekstraksi dikarenakan pengaruh pelarut yang digunakan untuk ekstraksi. Pelarut-pelarut polar seperti metanol dan etanol merupakan pelarut yang sangat luas digunakan dan efektif untuk ekstraksi komponen-komponen phenolik dari bahan alam. Untuk meningkatkan polaritas dalam ekstraksi fluida superkritis, dapat ditambahkan co-solvent seperti etanol, propanol, dan pelarut polar lainnya, sehingga dapat lebih banyak melarutkan komponen senyawa phenolic.

Hasil analisis kandungan fenol total ekstrak jahe dengan menggunakan ekstraksi fluida superkritis pada Gambar 2. menunjukkan kandungan fenol total tertinggi dihasilkan pada kondisi tekanan $16 \mathrm{MPa}$ sebesar 72,73 mg GEA/g ekstrak, kemudian diikuti pada tekanan 


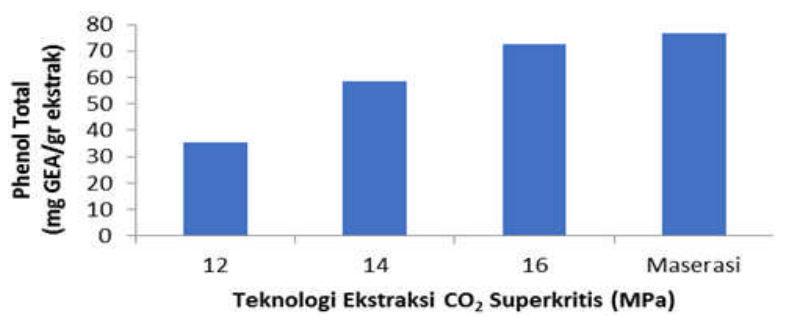

Gambar 2. Kandungan phenol total Zingiber officinale Rosc

$14 \mathrm{MPa}$ dan $12 \mathrm{MPa}$. Hal ini menunjukkan bahwa kondisi perbedaan tekanan pada ekstraksi jahe menggunakan ekstraksi fluida superkritis mempengaruhi kelarutan senyawa-senyawa phenolik.

Secara umum kekuatan senyawa fenol sebagai antioksidan bervariasi tergantung pada pertumbuhan lokasi dan kondisi lingkungan yang beragam, struktur senyawa fenol itu sendiri dan juga metode ekstraksi [7].

Hasil analisis penentuan kandungan flavonoid total dalam penelitian ini dengan persamaan kurva standar quercetin yaitu $\mathrm{y}=0,0111 \mathrm{x}+0,003\left(\mathrm{R}^{2}=0,9975\right)$ antara $0,35 \% \mathrm{~b} / \mathrm{b}$ sampai $1,18 \% \mathrm{~b} / \mathrm{b}$, diperlihatkan pada Gambar 3. Semakin tinggi kondisi tekanan pada ekstraksi fluida superkritis, semakin tinggi flavonoid total. Akan tetapi bila dibandingkan dengan metoda maserasi, kandungan flavonoid totalnya lebih tinggi. Hal ini terjadi karena senyawa flavonoid merupakan senyawa yang lebih bersifat polar, sehingga ketika di ekstraksi menggunakan pelarut polar pada ekstraksi maserasi akan semakin banyak senyawa flavonoid yang terekstrak.

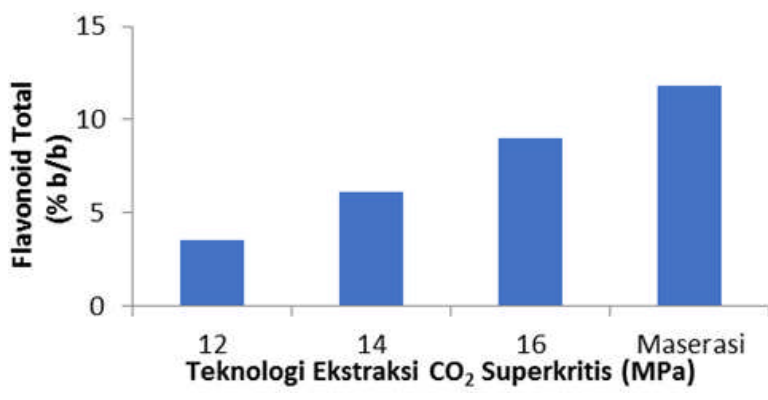

Gambar 3. Kandungan flavonoid total Zingiber officinale Rosc.

Aktivitas antioksidan, kandungan fenol total dan flavonoid total teringgi diperoleh pada tekanan ekstraksi fluida superkritis $16 \mathrm{MPa}$.

Fenol total dan flavonoid total merupakan senyawa antioksidan yang mempunyai aktivitas sebagai penangkal radikal bebas. Dari hasil penelitian aktivitas antioksidan dan kandungan fitokimia dari Zingiber officinale menunjukkan bahwa adanya korelasi berbanding lurus antara aktivitas antioksidan dengan kandungan fenol total dan flavonoid total. Semakin tinggi kandungan fenol total dan flavonoid totalnya, maka aktivitas antioksidannya semakin tinggi pula. Hal ini sejalan dengan penelitian yang telah dilakukan oleh peneliti sebelumnya [1].
Ekstrak jahe dengan menggunakan metoda maserasi kandungan fenol dan flavonoidnya relatif lebih tinggi daripada ekstrak jahe dengan menggunakan ekstraksi fluida $\mathrm{CO}_{2}$ superkritik, akan tetapi mempunyai aktivitas peredaman radikal bebas yang lebih rendah. Hal ini menunjukkan bahwa pada jahe, flavonoid total tidak selalu merupakan komponen utama yang berperan dalam memberikan kemampuan aktivitas antioksidan, ada kemungkinan senyawa lain atau interaksi antar senyawa yang dapat menentukan kemampuan aktivitas antioksidan dalam hal ini peredaman radikal bebas DPPH.

Hasil penelitian Mesomo dkk [14], melaporkan bahwa aktivitas antioksidan yang dihasilkan dari senyawa jahe relatif lebih tinggi dengan menggunakan ekstraksi fluida $\mathrm{CO}_{2}$ superkritik, karena ekstraksi fluida $\mathrm{CO}_{2}$ superkritik sangat cocok untuk mengekstrak senyawa termolabil terutama senyawa antioksidan. Hal ini sejalan dengan hasil yang diperoleh pada penelitian ini, bahwa aktivitas antioksidan jahe dengan menggunakan ekstraksi fluida $\mathrm{CO}_{2}$ superkritik memiliki aktivitas yang lebih aktif meskipun kandungan flavonoidnya rendah daripada kandungan flavonoid yang dihasilkan dengan metoda maserasi.

\section{KESIMPULAN}

Ekstraksi fluida superkritis pada jahe menghasilkan rendemen tertinggi 2,99 mg/g diperoleh pada suhu 40, tekanan $16 \mathrm{MPa}$ dan waktu ekstraksi 6 jam, dengan kandungan fenol total 72,73 mg GEA/g ekstrak, flavonoid total $0,90 \%(\mathrm{~b} / \mathrm{b})$ dan aktivitas antioksidan sebesar $63,66 \mu \mathrm{g} / \mathrm{mL}$. Pada ekstraksi fluida $\mathrm{CO}_{2}$ superkritik adanya korelasi berbanding lurus antara aktivitas antioksidan dengan kandungan fenol total dan flavonoid total. Semakin tinggi kandungan fenol total dan flavonoid totalnya, maka aktivitas antioksidannya semakin tinggi pula.

Ekstrak jahe dengan metoda maserasi dihasilkan rendemen $3,10 \mathrm{mg} / \mathrm{g}$, kandungan fenol total 76,68 $\mathrm{mg}$ GEA/g ekstrak, flavonoid total 1,18\% (b/b) dan aktivitas antioksidan sebesar $122,85 \mu \mathrm{g} / \mathrm{mL}$.

\section{UCAPAN TERIMAKASIH}

Penulis mengucapkan terimakasih kepada Kementrian Riset dan Teknologi yang telah memberikan dana penelitian pada Tahun Anggaran 2012-2016.

\section{DAFTAR ACUAN}

[1]. M. Amir, A. Khan, M. Mujeeb, A. Ahmad, S. Usmani and M. Akhta. "Phytochemical Analysis and in Vitro Antioxidant Activity of Zingiber officinale." Free Radicals and Antioxidants, vol.1, no. 4, pp. 75-81, 2011.

[2]. O. Babova, A. Occhipinti, A. Capuzzo and M.E. Maffei. "Extraction of Bilberry (Vaccinium 
Myrtillus) Antioxidants Using Supercritical/ Subcritical $\mathrm{CO}_{2}$ and Ethanol as Co-Solvent." Journal of Supercritical Fluids, vol. 107, pp. 358-363, 2016.

[3]. Y. Bellik." Total Antioxidant Activity And Antimicrobial Potency Of The Essential Oil And Oleoresin Of Zingiber Officinale Roscoe.” Asian Pacific Journal Tropical Disease, vol.4, no. 1, pp. 40-44, 2014.

[4]. M.C. Mesomo, M.L. Corazza, P.M. Ndiaye, O.R.D. Santa, L. Cardozo and A.D.P. Scheer. "Supercritical $\mathrm{CO}_{2}$ Extracts And Essential Oil Of Ginger (Zingiber Officinalle R.): Chemical composition and antibacterial activity." The Journal of Supercritical Fluids, vol. 80, pp. 44-49, 2013.

[5]. Q.Deng, K.G. Zinoviadou, C.M. Galanakis, V. Orlien, N. Grimi, E.ne Vorobiev, N. Lebovka and F.J. Barba. "The Effects Of Conventional And Nonconventional Processing On Glucosinolates And Its Derived Forms, Isothiocyanates: Extraction, Degradation, And Applications." Food Engeenering Review, vol. 7, no. 3, pp. 357-381, 2015.

[6]. I.R Kubra, K. Devender and L.J. Mohan.” Effect Of Microwave-Assisted Extraction On The Release Of Polyphenols From Ginger (Zingiber Officinale)." International Journal of Food Science and Technology, vol. 48, pp. 1828-1833, 2013.

[7]. J. Hu, Z. Guo, M. Glasius, K. Kristensen, L. Xiao and X. Xu. "Pressurized Liquid Extraction Of Ginger (Zingiber Officinale Roscoe) With Bioethanol: An Efficient And Sustainable Approach." Journal of Chromatography A, vol. 1218, pp. 5765-5773, 2011.

[8]. T. Moslavac, S. Jokic, D. Subaric,K.Aladi, J. Vukoja and N. Prce". Pressing and Supercritical $\mathrm{CO}_{2}$ Extraction of Camelina Sativa Oil". Industrial Crops and Products, vol. 54, pp. 122-129, 2014.

[9]. K. Czaikoski, M.C. Mesomo, R.L. Kruger, C.L. Queiroga and M.L. Corazza. "Extraction Of Campomanesia Xanthocarpa Fruit Using Supercritical $\mathrm{CO}_{2}$ and Bioactivity Assessments." The Journal of Supercritical Fluids, vol. 98, pp. 79-85, 2015.

[10]. F. Bashipour and S.M. Ghoreishi." Response Surface Optimization of Supercritical $\mathrm{CO}_{2}$ Extraction of $\alpha$-Tocopherol from Gel and Skin of Aloe Vera and Amond Leaves." The Journal of Supercritical Fluids, vol. 95, pp. 348-354, November 2014.

[11]. N.B. Rahal, F.J. Barba, D. Barth and I. Chevalot. "Supercritical $\mathrm{CO}_{2}$ Extraction of Oil, Fatty Acids and Flavonolignans from Milk Thistle Seed:
Evaluation of Their Antioxidant and Cytotoxic Activities in $\mathrm{CaCO}_{2}$ Cells". Food and Chemical Toxicology, vol. 83, pp. 275-282, September 2015.

[12]. K.C. Zancan, M.O.M. Marques, A.J. Petenate and M.A.A. Meireles." Extraction Of Ginger (Zingiber Officinale Roscoe) Oleoresin With $\mathrm{CO}_{2}$ And CoSolvents: A Study Of The Antioxidant Action Of The Extracts." Journal of Supercritical Fluids, vol. 24, pp. 57-76, 2002.

[13]. Harwoko, S. Pramono and A.E. Nugroho." Triterpenoid Fraction Of Centella Asiatica Leaves And In Vivo Antihypertensive Activity." International Food Research Journal, vol. 21, pp. 149-154, 2014.

[14]. M.C. Mesomo, AdP. Scheer, E. Perez, P.M. Ndiaye and M.L. Corazza. "Ginger Zingiber Officinale R Extracts Obtained Using Supercritical $\mathrm{CO}_{2}$ and Compressed Propane- Kinetics And Antioxidant Activity Evaluation." Journal of Supercritical Fluids, vol. 71, pp. 102-109, 2012.

[15]. K.L. Nagendra chari, D. Manasa, P. Srinivas and H.B. Sowbhagya." Enzyme-Assisted Extraction Of Bioactive Compounds From Ginger (Zingiber Officinale Roscoe)." Food Chemistry, vol. 139, pp. 509-514, 2013.

[16]. F. Pourmorad, S.J. Hosseinimehr and N. Shahabimajd." Antioxidant Activity, Phenol And Flavonoid Contents Of Some Selected Iranian Medicinal Plants." African Journal of Biotechnology, vol. 5, no. 11, pp. 1142-1145, 2006.

[17]. B. Sultana, F. Anwar and M. Ashraf." Effect Of Extraction Solvent/Technique On The Antioxidant Activity Of Selected Medicinal Plant Extracts." Molecules, vol. 14, pp. 2167-2180, 2009.

[18]. G. Oboh, A.J. Akinyemi and A.O. Ademiluyi. "Antioxidant And Inhibitory Effect Of Red Ginger (Zingiber Officinale Var. Rubra) And White Ginger (Zingiber Officinale Roscoe) on $\mathrm{Fe}^{2+}$ Induced Lipid Peroxidation In Rat Brain In Vitro.” Toxikologische Pathologie, vol. 64, no. 1-2, pp. 31-36, 2012.

[19]. M. Jun, Y. Fu, J. Hong, X. Wan, C. Yang and C. Ho. "Comparison of Antioxidant Activities of Isoflavones from Kudzu Root (Pueraria lobata Ohwi)." Journal of Food Science, vol. 68, pp. 21172122, 2003.

[20]. S. Mukherjee, N.Mandal, A. Dey and B. Mondal. "An Approach Towards Optimization Of The Extraction Of Polyphenolic Antioxidants From Ginger (Zingiber Officinale)." Journal of Food Science and Technology, pp. 1-8, 2012. 